\title{
ПРОГНОЗИРОВАНИЕ ЭКОНОМИЧЕСКОГО РАЗВИТИЯ ИРАНА С ПРИМЕНЕНИЕМ МОДЕЛИ САМУЭЛЬСОНА-ХИКСА
}

\author{
(c) 2021 Трегуб Илона Владимировна \\ доктор экономических наук, профессор департамента математики \\ Финансовый университет при Правительстве Российской Федерации, Россия, Москва \\ E-mail: ilonavl_fa@mail.ru \\ (c) 2021 Валенцукевич Кирилл Игоревич \\ студент-магистр \\ Финансовый университет при Правительстве Российской Федерации, Россия, Москва \\ E-mail:911valenc911@gmail.com
}

Предмет/тема. Исследование возможности применения классической модели СамуэльсонаХикса для прогнозирования динамики основных макроэкономических показателей экономики Ирана, выявление ключевых факторов и построение прогнозов развития страны.

Цели/задачи. Выявление применимости модели Самуэльсона-Хикса на примере экономики Ирана. Были поставлены следующие задачи: раскрытия особенностей Иранской экономики; анализ классической модели Самуэльсона-Хикса и приведение его в необходимую для исследования форму; выполнение корреляционного анализа и построение точечной диаграммы; проведение регрессионного анализа и построение уравнений; проверка условий Гаусса-Маркова, обоснования полученных результатов.

Методология. В процессе исследования были применены методы теоретического исследования, анализ и синтез, группировка и сравнение, а также корреляционно-регрессионный анализ.

Результаты/выводы. В ходе проведения исследования были раскрыты особенности Иранской экономики, была выведена приведенная модель Самуэльсона-Хикса, выполнен корреляционнорегрессионный анализ, получены уравнения регрессии и сделаны прогнозы по ним, а также раскрыты условия Гаусса-Маркова и тестирование модели на их соблюдение.

Ключевые слова: Регрессионная модель; анализ данных; метод наименьших квадратов; инвестиции; Иран; модель Самуэльсона-Хикса; условия Гаусса-Маркова.

Иранскую экономику можно охарактеризовать как смешанную с очень развитым государственным сектором. Следует отметить, что 60\% предприятий находятся в зоне централизованного планирования государства. Широко распространенный контроль цен и субсидии являются важным компонентом экономики Ирана. Правительство принимает активное участие в развитии экономики, разрабатывая пятилетние планы, направленные на ее высокий и стабильный рост. Исламская Республика Иран характеризуется также тем, что эта страна занимает второе место в мире по запасам природного газа, а также одну из лидирующих позиций по запасам нефти. Но несмотря на то, что в стране также развиты сельское хозяйство, обрабатывающая промышленность и другие отрасли, не имеющие прямого отношения к сырьевой промышленности, следует отметить, что иранская экономика в большей степени зависит от продажи полезных ископаемых за рубеж.

Поговорим о модели, которую мы используем в этом исследовании; мы будем использовать модель Самуэльсона-Хикса. Следует отметить, что данная модель по своей сути является более совершенным динамическим аналогом кейнсианской модели.

Особенность этой модели еще и в том, что она применима только для закрытой экономики, но поскольку мы сейчас наблюдаем тесную глобализацию и рост отношений между странами, то эта модель может быть применена только к странам, которые по своему типу и государственному устройству близки к закрытой экономике. Условия замкнутой экономики страны в текущий период времени описываются переменными: Валовой внутренний продукт $\left(\mathrm{Y}_{\mathrm{t}}\right)$, уровень потребления $\left(\mathrm{C}_{\mathrm{t}}\right)$, объем инвестиций $\left(\mathrm{I}_{\mathrm{t}}\right)$ и государственные расходы $\left(\mathrm{G}_{\mathrm{t}}\right)$.

При создании модели Самуэльсона Хикса 
необходимо иметь в виду следующие моменты:

1) $G_{t}$ растет с постоянной скоростью роста;

2) Текущий уровень $C_{t}$ объясняется уровнем Yt в прошлом периоде, увеличивающимся вместе с ним, но с меньшей скоростью;

3) Сумма $\mathrm{I}_{t}$ прямо пропорциональна увеличению $\mathrm{Y}_{\mathrm{t}}$ за предыдущий период; $\mathrm{I}_{\mathrm{t}}$.

4) Текущее значение $Y_{t}$ - это сумма $C_{t}, G_{t}$,

Откуда мы знаем, что эконометрика интерпретирует экономические события с помощью математического языка.

При переводе приведенных выше утверждений на математический язык мы получаем исходную модель Самуэльсона Хикса:

$$
\left\{\begin{array}{c}
\mathrm{C}_{t}=\alpha_{0}+\alpha_{1} * \mathrm{Y}_{t-1}+\varepsilon_{t}, \quad 0<\alpha_{1}<1 \\
\mathrm{I}_{t}=\beta_{0}+\beta_{1}\left(\mathrm{Y}_{t-1}-\mathrm{Y}_{t-2}\right)+\omega_{t}, \quad \beta>0 \\
\mathrm{G}_{t}=\gamma_{1} \mathrm{G}_{t 1}+\mu_{t}, \\
\mathrm{Y}_{t}=\mathrm{C}_{t}+\mathrm{I}_{t}+\mathrm{G}_{t} \\
\mathrm{E}\left(\varepsilon_{t}\right)=0 ; \mathrm{E}\left(\omega_{t}\right)=0 ; \mathrm{E}\left(\mu_{t}\right)=0 \\
\sigma\left(\varepsilon_{t}\right)=\text { const } ; \sigma\left(\omega_{t}\right)=\mathrm{const} ; \sigma\left(\mu_{t}\right)=\mathrm{const}
\end{array}\right.
$$

Мы получили исходную модель, которую мы не сможем использовать в нашем исследовании, поэтому мы должны сделать из нее уменьшенную модель. Следует также отметить, что обязательным условием эконометрической модели является включение в нее случайной ошибки, поэтому мы изначально рассматривали случайную ошибку.

После выполнения некоторых операций мы получаем уменьшенную модель Самуэльсона Хикса:

$$
\left\{\begin{array}{c}
\mathrm{C}_{t}=\alpha_{0}+\alpha_{1} * \mathrm{Y}_{t-1}+\varepsilon_{t}, 0<\alpha_{1}<1 \\
\mathrm{I}_{t}=\beta_{0}+\beta_{1} *\left(\mathrm{Y}_{t-1}-\mathrm{Y}_{t-2}\right)+\mu_{t}, \beta>0 \\
\mathrm{G}_{t}=\gamma_{1} * \mathrm{Y}_{t-1}+\omega_{t} \\
\mathrm{Y}_{t}=\tau_{0}+\tau_{1} * \mathrm{Y}_{t-1}+\tau_{2} * \mathrm{Y}_{t-2}+\gamma_{1} * \mathrm{G}_{t-1}+\varphi_{t}
\end{array}\right.
$$

Выполнив некоторые преобразования, мы получили редуцированную форму нашей модели и теперь можем использовать ее в наших исследованиях.

В начале исследования мы собрали все необходимые данные с помощью сайта Всемирного банка, выбрали ВВП, расходы на конечное потребление, Прямые иностранные инвестиции, общегосударственные расходы. Все показатели были взяты в текущих долларах США.

Мы рассчитали общую корреляцию между всеми показателями, использованными для ис- следования, и сделали следующие выводы:

- Мы можем наблюдать очень сильную линейную положительную корреляцию 0,99 между расходами на конечное потребление и ВВП.;

- Между прямыми иностранными инвестициями и ВВП наблюдается сильная линейная положительная корреляция 0,74 ;

- Общегосударственные расходы и ВВП отрицательно коррелируют $-0,58$, это означает, что когда значения одной переменной уменьшаются, значения другой увеличиваются.

Далее мы провели корреляционный анализ между показателями, используемыми в модели Самуэльсона Хикса.

Исследуя первую модель потребления, мы можем заметить очень сильную положительную линейную корреляцию. Показатель корреляции равен 0, 968.

Для каждой модели был построен разброс вставки для наглядности, мы не будем демонстрировать все графики, мы продемонстрируем только пример первой модели (рис. 1).

Как видно из рисунка 1 , точки рассеяния образуют определенную линию, что говорит о высокой корреляции.

В других моделях мы наблюдаем несколько иную картину, в модели 2 уровень корреляции равен 0,267, этот уровень указывает на очень слабую корреляцию между переменными. В модели 3 корреляция средняя -0,67. В модели 4 рассматривается наибольшее количество переменных, и наблюдается сильная связь между ВВП текущего года и ВВП предыдущих лет, а в случае общегосударственных расходов прошлого года корреляция связи отрицательна -0,537.

После определения корреляций между показателями в моделях, а также построения графиков мы переходим к следующему этапу, а именно к выполнению регрессионного анализа.

Мы не будем подробно останавливаться на каждом показателе, полученном с помощью регрессионного анализа, так как это не является основной целью исследования. Рассмотрим только полученное уравнение регрессии и сделаем из него вывод.

Для модели 1:

Уравнение: $\mathrm{C}_{t}=31,6+0,51 \mathrm{Y}_{t-1}+\varepsilon_{t}$

Вывод: если $\mathrm{Y}_{\mathrm{t}-1}$ увеличится на 1 млрд. Иранских реалов, потребление увеличится на 0,53 млрд. Иранские реалы. 


\section{$C=f\left(G D P_{t-1}\right)$}

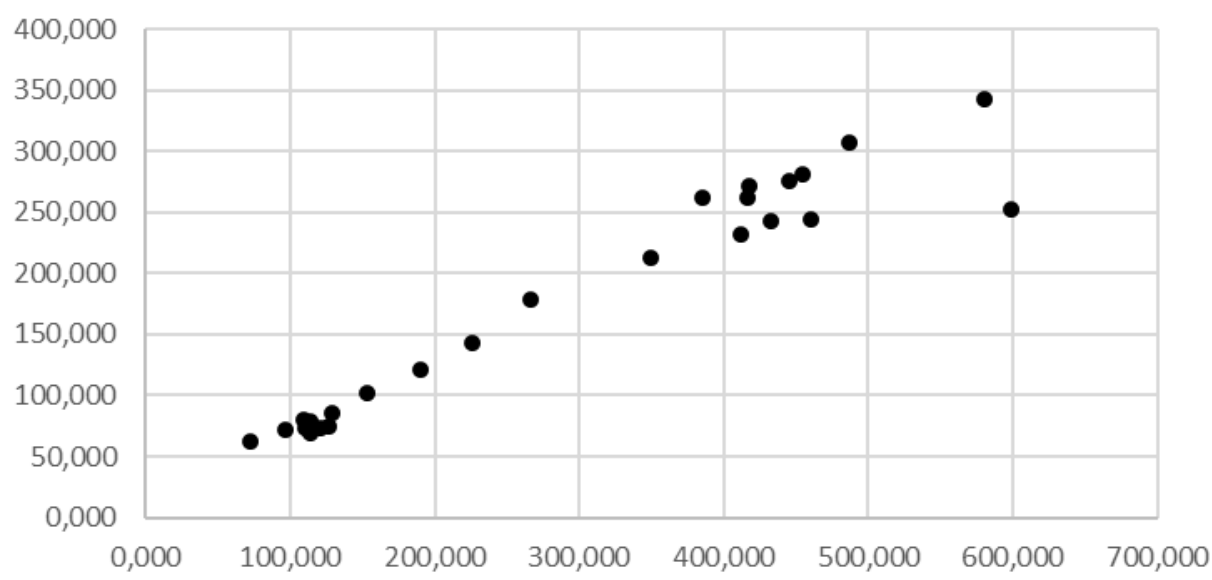

Рисунок 1. Модель рассеяния 1

Для модели 2:

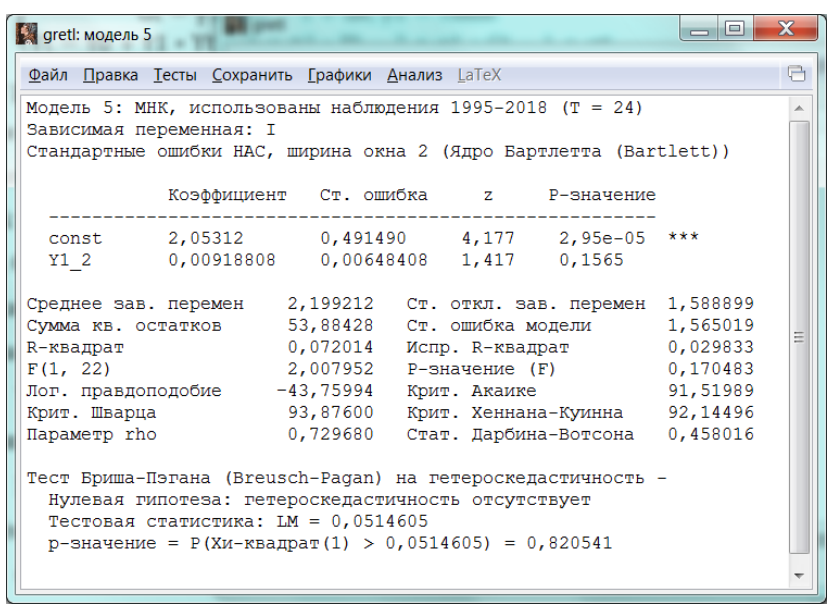

Рисунок 2. Статистика классического инвестиционного уравнения.

Уравнение:

$\mathrm{I}_{t}=2,03+0,0093\left(\mathrm{Y}_{t-1}-\mathrm{Y}_{t-2}\right)+\omega_{t}$

В классической модели $\mathrm{R}^{2}$ очень низок. Регрессия не является статистически значимой. Коэффициент наклона перед управляющей переменной также незначителен. Остатки гомоскедастичны, но автокоррелированы, что нарушает третью презумпцию теоремы Гаусса - Маркова. Все это привело к необходимости провести модификацию классической модели Самуэльсона Хикса. В результате наших исследований нам удалось получить новое уравнение для инвестиционной функции. Оценка коэффициентов нашей модели приведена на рис. 3 .

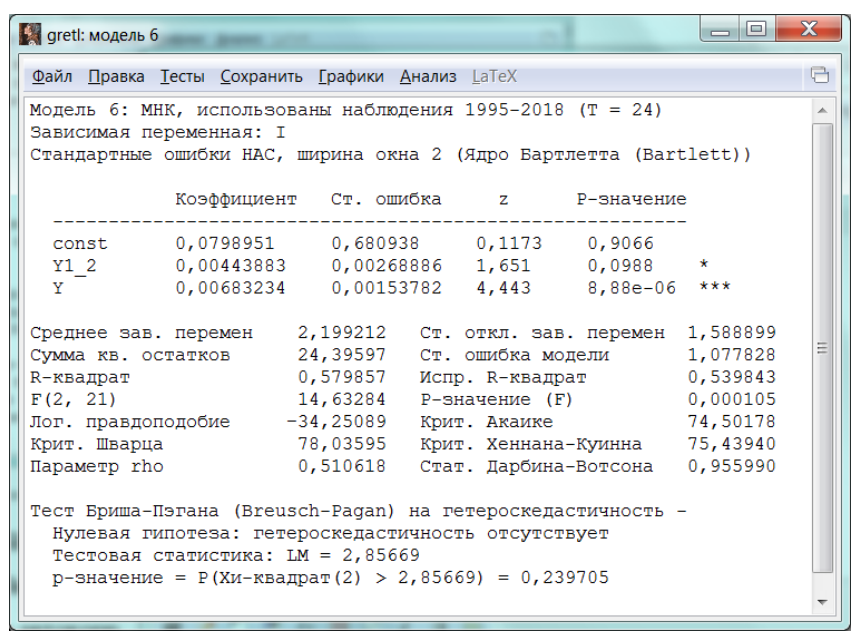

Рисунок 3. Статистика модифицированного инвестиционного уравнения.

Модифицированное уравнение:

$$
\mathrm{I}_{t}=0.07+0,004\left(\mathrm{Y}_{t-1}-\mathrm{Y}_{t-2}\right)+0.007 \mathrm{Y}_{t}+\omega_{t}
$$

Вывод: В модифицированной модели все управляющие переменные значимы. Останки гомоскедастичны. Константа критерия ДурбинаУотсона переместилась из зоны, однозначно сигнализирующей о наличии автокорреляции, в зону неопределенности.

Коэффициент детерминации показывает, что, в отличие от классической модели, в которой инвестиции объяснялись всего на 7\%, в модифицированной модели объяснительная сила уравнения возросла до 53\%. Более того, регрессия статистически значима. 
Для модели 3:

Уравнение: $\mathrm{G}_{t}=0.98 * \mathrm{G}_{t-1}+\mu_{t}$

Вывод: если $\mathrm{G}_{\mathrm{t}-1}$ увеличится на 1 млрд. LCU, то текущий $G$ увеличится на 0,98 млрд. LCU

Для модели 4:

Уравнение:

$Y_{t}=-58,1+1,34 * \mathrm{Y}_{t-1}-0,37 * \mathrm{Y}_{t-2}+6,44 * \mathrm{G}_{t-1}+\varphi_{t}$

Вывод: если текущее значение ВВП увеличится на один миллиард. Иранских реалов, ВВП в будущем увеличится на 1,34 млрд. иранских реалов.

В то же время, если текущие государственные расходы увеличатся на 1 млрд. иранских реалов, то ВВП в следующем году увеличится на 6,329 млрд. иранских реалов.

Для регрессионного анализа, основанного на обычном методе наименьших квадратов, чтобы получить наилучшие возможные результаты, случайная ошибка должна удовлетворять определенным условиям, известным как условия Гаусса-Маркова. При выполнении всех условий он обеспечивает наилучшую несмещенную, эффективную и предельно сходящуюся оценку вектора параметров.

Есть четыре условия, которые должны быть выполнены, и следует отметить, что даже если одно из них не выполнено, можно сказать, что модель не должна использоваться, и либо внести коррективы, либо заменить показатели в модели.

Начнем наше исследование с первого условия. Она состоит в том, что математическое ожидание случайной ошибки в каждой модели должно быть равно нулю. Вычисляя математическое ожидание в каждой модели, мы получили $\mathrm{E}(\mathrm{u})=0$, это означает, что иногда случайная ошибка будет отрицательной, иногда положительной, но она не должна иметь систематического смещения. Поскольку мы получили искомое значение, можно сказать, что условие № 1 Гаусса Маркова было выполнено.

Далее нам нужно проверить второе условие, выполнив тест Гольдфельда-Квандта, он нужен для проверки отклонения от гомоскедастичности.

Если GQ и 1 / GQ меньше или равны Fcrit, то выполняется второе условие GM. Невязки го- москедастичны, а коэффициенты модели беспристрастны, последовательны, эффективны и точны. В противном случае это сигнал о пропущенной переменной. В нашем случае второе условие Гаусса-Маркова изначально выполнялось не для всех уравнений модели. Вот почему мы использовали взвешенные наименьшие квадраты для устранения гетероскедастичности (WLS). B результате мы получили гомоскедастические невязки во всех уравнениях модифицированной модели Самуэльсона Хикса.

Далее мы должны перейти к третьему условию, в этом условии мы должны проверить отсутствие автокорреляции, мы проверим этот факт, вычисляя статистику Дурбина-Уотсона остатков е.

Если константа DW лежит между du и 4-du то выполняется условие GM № 3, автокорреляции в остатках нет, коэффициенты модели являются оптимальными, последовательными, эффективными, управляемыми или точными. Если константа DW лежит между нулем и dl, то мы имеем положительную автокорреляцию в остатках. Если константа DW лежит между 4-dl и 4 , то наши остатки отрицательно автокоррелированы.

Если константа DW находится между 4-du и 4-dl, то нет никакой информации об уровнях значимости изменения автокорреляции, вычислите новую константу и получите другую таблицу, или мы не можем использовать другой тест.

Во всех уравнениях, кроме второго, выполняется третье условие теоремы Гаусса Маркова. Во втором уравнении нет однозначной информации о наличии или отсутствии автокорреляции. Возможно, это сигнал отсутствующей переменной. Однако поиск новой объясняющей переменной выходит за рамки нашего исследования, поскольку нас интересует модель Самуэльсона Хикса и ее модификация набором управляющих переменных этой модели.

На основании проведенных исследований можно сделать вывод, что классическая модель Самуэльсона Хикса не совсем подходит для моделирования. Не все уравнения модели могут адекватно описать динамику макроэкономических показателей страны, таких как инвестиции, по отношению к такой стране, как Иран. В основном это связано с тем, что модель используется только для закрытой экономики, а в современном мире, в условиях роста постоянной глобализации в чистом виде, трудно найти такие 
экономики. Тем не менее нам удалось провести модификацию поведенческих уравнений модели, которая теперь полностью учитывает текущую рыночную среду и особенности националь- ной экономики Ирана. Разработанные модели адекватны и пригодны для прогнозирования и принятия управленческих решений.

\section{Библиографический список}

1. Трегуб И.В., Шапиро М.Я.Имитационное моделирование спроса на дополнительные услуги сотовой связи (на примере работы сервиса «Новости») / Вестник Финансовой академии. 2006. № 4 (40). С. 89-96. 16

2. Трегуб И. В. Моделирование динамики цены биржевых инструментов на российском фондовом рынке методами технического анализа // Вестник Московского государственного университета леса - Лесной вестник. 2005. № 3. С. 156-170.

3. Трегуб И.В. Прогнозирование инновационного развития рынка телекоммуникаций // Обозрение прикладной и промышленной математики. 2013. Т. 20. № 2. С. 186-187.

4. Трегуб И.В. Методы визуализации модельных исследований / Saarbrucken, 2013.

5. Tregub I. V. The capital market model on the example of Norway / В сборнике: Forum for Reseach in Empirical Internation Trade. Сан Рафаэль, 2015.

6. Шкляев Л.О., Трегуб А.В., Трегуб И.В. Сравнительный анализ моделей оценки кредитного риска эмитента корпоративных облигаций на российском долговом рынке // Вестник Московского государственного университета леса - Лесной вестник. 2013. № 3. С. 215-221.

7. Кузнецов В.Д., Трегуб И. В. Математическое моделирование динамики экономических показателей (на примере выручки IT компании) // Современные проблемы науки и образования. 2013. № 6. С. 424 


\title{
APPLICATION OF THE SAMUELSON-HICKS MODEL ON THE EXAMPLE OF IRAN
}

\author{
(C) 2021 Tregub Ilona Vladimirovna \\ Doctor of Economics, Professor of the Department of Mathematics \\ Financial university under the Government of the Russian Federation, Moscow, Russia \\ E-mail: ilonavl_fa@mail.ru \\ (C) 2021 Valentsukevich Kirill Igorevich \\ The master student \\ Financial university under the Government of the Russian Federation, Moscow, Russia \\ E-mail:911valenc911@gmail.com
}

Subject / topic. The study of the possibility of using the Samuelson-Hicks model and the assessment of compliance with the Gauss-Markov conditions on the example of Iran.

Goals / objectives. Identification of the applicability of the Samuelson-Hicks model on the example of the Iranian economy. The following tasks were set: to reveal the features of the Iranian economy; to analyze the Samuelson-Hicks model and bring it into the form necessary for the study; to perform a correlation analysis and build a dot diagram; to conduct a regression analysis and build equations; to check the Gauss-Markov conditions and justify the results obtained.

Methodology. In the course of the research, the methods of theoretical research, analysis and synthesis, grouping and comparison, as well as correlation and regression analysis were applied.

Results / conclusions. In the course of the study, the features of the Iranian economy were revealed, the Samuelson-Hicks model was derived, the correlation and regression analysis was performed, the regression equations were obtained and forecasts were made for them, as well as the Gauss-Markov conditions were disclosed and the model was tested for their compliance.

Keywords: Regression model; data analysis; least square method; investment; Iran; Samuelson-Hicks model; Gauss Markov conditions.

Iran is a country in a Western Asia. According to its state structure, Iran is an Islamic republic. Iran ranks 25th in terms of GDP and 101st in terms of GDP per capita. By the number of people, Iran ranks 17 th in the world.

Iran's economy can be described as mixed with a very developed public sector. It should be noted that $60 \%$ of enterprises are located in the central planning zone of the state. Widespread price controls, and subsidies are an important component for Iran's economy. The Government takes an active part in the development of the economy by developing five-year plans aimed at its high and stable growth. The Islamic Republic of Iran is also characterized by the fact that this country occupies the second place in the world in terms of natural gas reserves, as well as one of the leading positions in terms of oil reserves. But despite the fact that the country also has developed agriculture, manufacturing and other sectors that are not directly related to the raw materials industry, it should be noted that the Iranian economy is more dependent on the sale of mineral resources abroad. The main buyers of natural resources are countries such as China, In- dia, South Korea, and Turkey.

In Iran, unemployment is a serious problem, especially among the young population, and due to the lack of jobs, young people must leave the country. Also, do not forget about the level of inflation, it is also at a significantly serious level. Although Iran is considered a rich Asian country, with a high level of education, but the strong impact of economic sanctions, as well as the not very successful policy of the state, especially in the banking sector, contributed to the weakening of the local currency, a decrease in GDP growth, as well as an increase in inflation and unemployment. At the moment, Iran has a low rating of economic freedom, and opening a business for foreign citizens is not easy in this country, which implies a low level of investment and a rather unattractive economic environment for foreign agents. As a result, it leads to a slowdown in economic development, and sanctions from foreign countries make it impossible to enter the world stage.

Now let's talk about the model we use in this study; we will use the Samuelson-Hicks model. It should be noted that this model is, in its essence, 
a more advanced dynamic analog of the Keynesian model.

The peculiarity of this model is also that it is applicable only for a closed economy, but since we are now seeing a close globalization and an increase in the relationship between countries, this model can only be applied to countries that are similar in their type and state structure to a closed economy. The conditions of the closed economy of the country in the current period of time are described by variables: Gross domestic product $\left(\mathrm{Y}_{\mathrm{t}}\right)$, level of consumption $\left(\mathrm{C}_{\mathrm{t}}\right)$, the amount of investment $\left(\mathrm{I}_{\mathrm{t}}\right)$ and government spending $\left(\mathrm{G}_{t}\right)$.

When creating the Samuelson Hicks model, you need to keep in mind the following points:

1) $G_{t}$ grow at a constant rate of growth;

2) The current $C_{t}$ level is explained by the $Y_{t}$ level in the past period, increasing with it, but at a lower rate;

3) The amount $I_{t}$ is directly proportional to the increase $Y_{t}$ for the previous period; $\mathrm{I}_{\mathrm{t}}$.

4) The current value of $Y_{t}$ is the sum of $C_{t}, G_{t}$,

How we know that econometrics interprets economic events using mathematical language.

When translating the above statements into mathematical language, we get the initial model of Samuelson Hicks:

$$
\left\{\begin{array}{c}
\mathrm{C}_{t}=\alpha_{0}+\alpha_{1} * \mathrm{Y}_{t-1}+\varepsilon_{t}, \quad 0<\alpha_{1}<1 \\
\mathrm{I}_{t}=\beta_{0}+\beta_{1}\left(\mathrm{Y}_{t-1}-\mathrm{Y}_{t-2}\right)+\omega_{t}, \quad \beta>0 \\
\mathrm{G}_{t}=\gamma_{1} \mathrm{G}_{t 1}+\mu_{t}, \\
\mathrm{Y}_{t}=\mathrm{C}_{t}+\mathrm{I}_{t}+\mathrm{G}_{t} \\
\mathrm{E}\left(\varepsilon_{t}\right)=0 ; \mathrm{E}\left(\omega_{t}\right)=0 ; \mathrm{E}\left(\mu_{t}\right)=0 \\
\sigma\left(\varepsilon_{t}\right)=\text { const } ; \sigma\left(\omega_{t}\right)=\mathrm{const} ; \sigma\left(\mu_{t}\right)=\mathrm{const}
\end{array}\right.
$$

We have obtained an initial model that we will not be able to use in our study, so we should make a reduced model out of it. It should also be noted that a prerequisite for econometric models is the inclusion of a random error in it, so we initially considered the random error.

After performing some operations, we get the reduced Samuelson Hicks model:

$$
\left\{\begin{array}{c}
\mathrm{C}_{t}=\alpha_{0}+\alpha_{1} * \mathrm{Y}_{t-1}+\varepsilon_{t}, 0<\alpha_{1}<1 \\
\mathrm{I}_{t}=\beta_{0}+\beta_{1} *\left(\mathrm{Y}_{t-1}-\mathrm{Y}_{t-2}\right)+\mu_{t}, \beta>0 \\
\mathrm{G}_{t}=\gamma_{1} * \mathrm{Y}_{t-1}+\omega_{t} \\
\mathrm{Y}_{t}=\tau_{0}+\tau_{1} * \mathrm{Y}_{t-1}+\tau_{2} * \mathrm{Y}_{t-2}+\gamma_{1} * \mathrm{G}_{t-1}+\varphi_{t}
\end{array}\right.
$$

After performing some transformations, we got the reduce form of our model and can now use it in our research.

At the beginning of the study, we collected all the necessary data using the World Bank website, we chose GDP, Final consumption expenditure, Foreign direct investment, General government spending. All indicators were taken in current US\$.

We calculated the overall correlation between all the indicators used for the study and made the following conclusions:

- We can observe a very strong linear positive correlation 0,99 between Final consumption expenditure and GDP;

- Between Foreign direct investment and GDP we can observe strong linear positive correlation 0,74 ;

- General government spending and GDP negatively correlated $-0,58$, it mean when the values of one variable decrease, the values of the other increase.

Next, we performed a correlation analysis between the indicators used in the Samuelson Hicks model.

Exploring the first model of consumption we can notice a Very strong positive linear correlation. The correlation indicator is equal to 0,968 .

For each model, an insert scatter was built for clarity, we will not demonstrate all the graphs, we will only demonstrate the example of the first model (see Picture 1). As we can see from Picture 1, that the scattering points form a certain line, this tells us about the high correlation.

In other models, we observe a slightly different picture, in model 2 , the correlation level is 0,267 , this level indicates a very weak correlation between the variables. In model 3 , the correlation is average, at 0,67 . In model 4 , the largest number of variables is considered, and a strong relationship is observed between the GDP of the current year and the GDP of previous years, and in the case of General government spending last year the relationship correlation is negative $-0,537$.

After determining the correlations between the indicators in the models, as well as building graphs, we move on to the next stage, namely, performing regression analysis.

We will not go into detail on each indicator obtained using regression analysis, since this is not the main purpose of the study. We will consider only the obtained regression equation and make a conclusion from it. 
$C=f\left(G D P_{t-1}\right)$

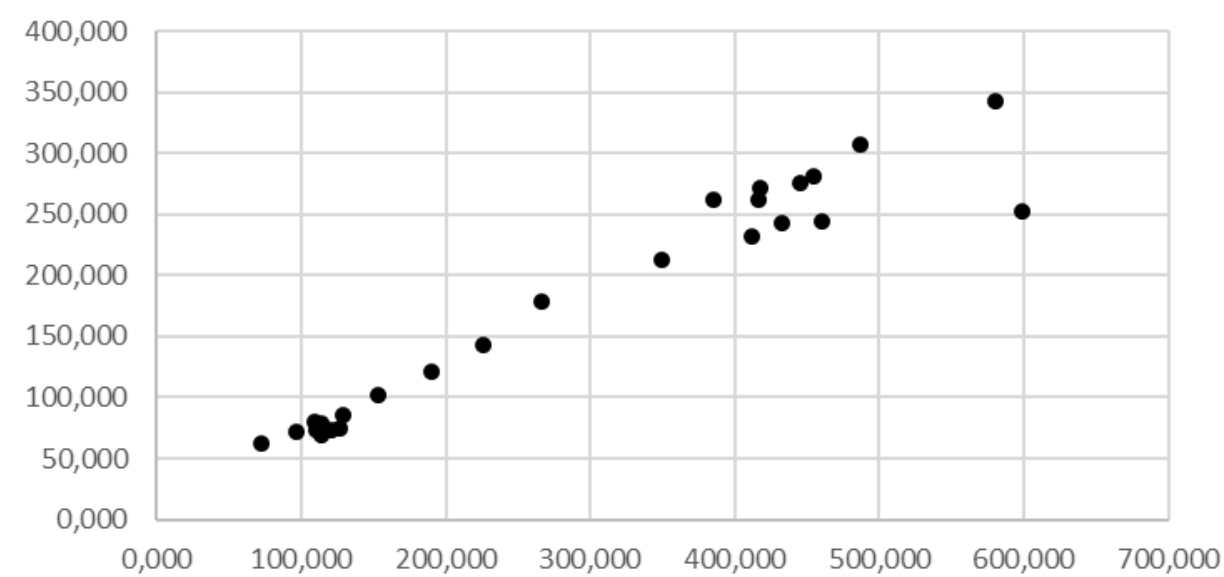

Picture 1. Insert scatter model 1

\section{For model 1:}

Equation: $\mathrm{C}_{t}=31,6+0,51 \mathrm{Y}_{t-1}+\varepsilon_{t}$

Conclusion: If $\mathrm{Y}_{\mathrm{t}-1}$ increases by $1 \mathrm{bln}$. Iranian reals, the consumption will increase by $0,53 \mathrm{bln}$. Iranian reals.

\section{For model 2:}

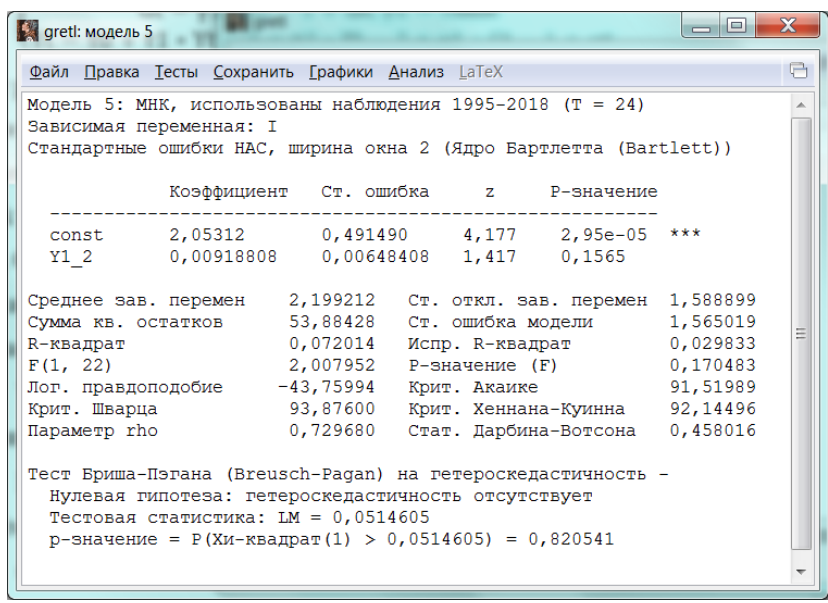

Fig.1. Statistics of Classic Investment Equation.

Equation: $\mathrm{I}_{t}=2,03+0,0093\left(\mathrm{Y}_{t-1}-\mathrm{Y}_{t-2}\right)+\omega_{t}$

In the classical model, $\mathrm{R}^{2}$ is very low. The regression is not statistically significant. The slope coefficient before the control variable is also insignificant. The residuals are Homoscedastic, but autocorrelated, thus violating the third presumption of the Gauss - Markov theorem. All this led to the need to carry out a modification of the classical model of Samuelson Hicks. As a result of our research, we managed to obtain a new equation for the investment function. The estimation of the coefficients of our model is shown in Fig. 2.

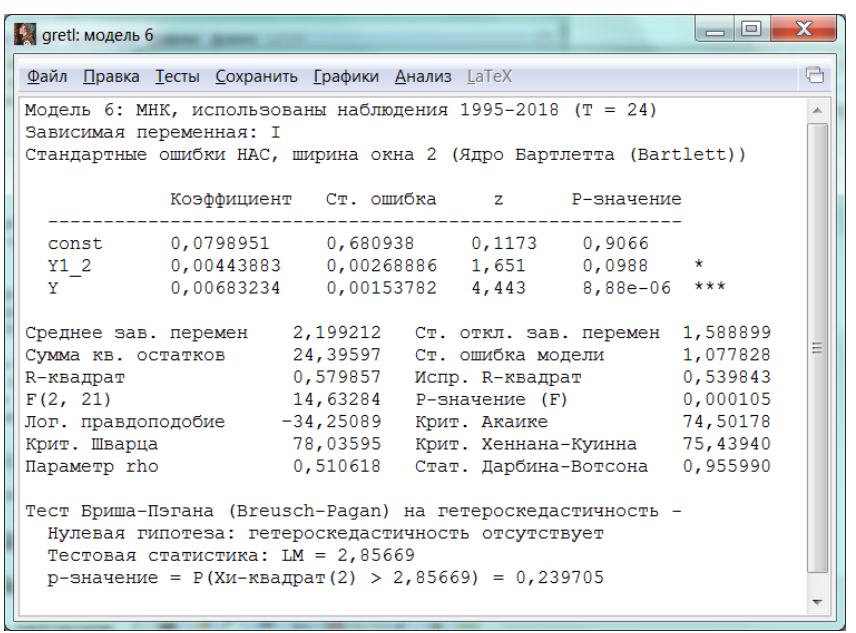

Fig. 2. Statistics of Modified Investment Equation

Modified Equation:

$$
\mathrm{I}_{t}=0.07+0,004\left(\mathrm{Y}_{t-1}-\mathrm{Y}_{t-2}\right)+0.007 \mathrm{Y}_{t}+\omega_{t}
$$

Conclusion: In the modified model, all control Variables are significant. The remains are homoscedastic. The constant of the Darbin-Watson test has moved from the zone that unambiguously signals the presence of autocorrelation to the zone of uncertainty.

The coefficient of determination shows that, in contrast to the classical model, in which investments were explained by only 7 percent, in the mod- 
ified model the explanatory power of the equation increased to 53 percent. Moreover, the regression is statistically significant.

\section{For model 3:}

Equation: $\mathrm{G}_{t}=0.98 * \mathrm{G}_{t-1}+\mu_{t}$

Conclusion: If Gt- 1 increases by 1 bln LCU, the current $\mathrm{G}$ will increase by 0,98 bln LCU

\section{For model 4:}

\section{Equation:}

$$
\begin{aligned}
& Y_{t}=-58,1+1,34 * Y_{t-1}-0,37 * Y_{t-2} \\
& +6,44 * \mathrm{G}_{t-1}+\varphi_{t}
\end{aligned}
$$

Conclusion: If current value of GDP increases by one bln. Iranian reals, the GDP in future will increase by 1,34 bln Iranian reals.

At the same time, if current government spending increases by 1 bln Iranian reals, the GDP will increase by 6,329 bln Iranian reals in the next year.

For a regression analysis based on the usual least-squares method to produce the best possible results, the random error must satisfy certain conditions known as the Gauss-Markov conditions. When all conditions are met, it provides the best unbiased, efficient, and limit-convergent estimate of the parameter vector.

There are four conditions that must be met, and it should be noted that even if one of them is not met, we can say that the model should not be used, and either make adjustments or replace the indicators in the model.

Let's start our research with the first condition. It consists of the fact that the mathematical expectation of a random error in each model should be zero. By calculating the mathematical expectation in each model, we got $\mathrm{E}(\mathrm{u})=0$, this means that sometimes the random error will be negative, sometimes positive, but it should not have a systematic bias. Since we got the desired value, we can say that condition number 1 of the Gauss Markov was met.

Next, we need to check the second condition by performing the Goldfeld-Quandt test, it is needed to check the deviation from homoscedasticity.

If GQ and 1 / GQ are less than or equal to Fcrit, then the second GM condition is met. The residuals are homoscedastic and the model coefficients are impartial, consistent, efficient, and accurate. Oth- erwise, it is a signal about an omitted variable. In our case, the second Gauss-Markov condition was initially fulfilled not for all equations of the model. This is why we used weighted least squares to eliminate heteroscedasticity (WLS). As a result, we obtained homoscedastic residuals in all equations of the modified Samuelson Hicks model.

Next, we must go to the third condition, in this condition we have to check for the absence of autocorrelation, we will check this fact by calculating the Durbin-Watson statistics of the residuals of e.

If DW constant lies between du and 4-du - then GM condition number 3 is satisfied, there is no autocorrelation in residuals, coefficients of the model are upbeats, consistent, efficient, presided or accurate. If DW constant lies between zero and dl, we have positive autocorrelation in residuals. If DW constant lies between 4-dl and 4, our residuals are negative autocorrelated.

If the DW constant is between 4-du and 4-dl, there is no information about the significance levels of the autocorrelation change, calculate the new constant and get another table, or we cannot use another test.

In all equations, except for the second, the third condition of the Gauss Markov theorem is satisfied. In the second equation, there is no unambiguous information about the presence or absence of autocorrelation. In perhaps it is a signal of a missing variable. However, the search for a new explanatory variable is beyond the scope of our study, since we are interested in the Samuelson Hicks model and its modification by a set of control variables of this model.

Based on the conducted research, we can conclude that the classical model of Samuelson Hicks is not quite suitable for modeling. Not all model equations can adequately describe the dynamics of a country's macroeconomic indicators, such as investments, in relation to a country such as Iran. This is mainly due to the fact that the model is used only for a closed economy, and in the modern world, in the context of the growth of constant globalization in its pure form, it is difficult to find such economies. Nevertheless, we managed to carry out a modification of the behavioral equations of the model, which now fully takes into account the current market environment and the peculiarities of the national economy of Iran. The developed models are adequate and suitable for forecasting and making management decisions. 


\section{Refereces}

1. Tregub I. V., Shapiro M. Ya. Imitational modeling of demand for additional cellular services (on the example of the work of the «News» service) / Bulletin of the Financial Academy. 2006. No. 4 (40). pp. 89-96. 16

2. Tregub I. V. Modeling of price dynamics of exchange-traded instruments on the Russian stock market by methods of technical analysis // Vestnik Moskovskogo gosudarstvennogo universiteta lesa-Lesnoy vestnik. 2005. No. 3. pp. $156-170$.

3. Tregub I. V. Prognozirovanie innovatsionnogo razvitiya rynka telekomekatsii [Forecasting of innovative development of the telecommunications market]. 2013. Vol. 20. no. 2. pp. 186-187.

4. Tregub I.V. Methods of visualization of model research / Saarbrucken, 2013.

5. Tregub I. V. The capital market model on the example of Norway / In the collection: Forum for Research in Empirical International Trade. San Rafael, 2015.

6. Shklyaev L. O., Tregub A. V., Tregub I. V. Comparative analysis of models for assessing the credit risk of an issuer of corporate bonds on the Russian debt market.Vestnik Moskovskogo gosudarstvennogo universiteta lesa - Lesnoy vestnik. 2013. No. 3. pp. 215-221.

7. Kuznetsov V. D., Tregub I. V. Mathematical modeling of the dynamics of economic indicators (on the example of revenue of an IT company) / / Modern problems of science and education. 2013. No. 6. p. 424 